\title{
Serendipitous Discovery of Factor VII Deficiency and the Ensuing Dilemma
}

Jayadev M. UMAKANTHAN ${ }^{a}$, Prajwal DHAKAL ${ }^{b}$, Krishna GUNDABOLU ${ }^{\mathrm{a}, \mathrm{c}}$, Scott A. KOEPSELL ${ }^{d}$, Muhamed BALJEVIC ${ }^{a, c}$

aDivision of Hematology and Oncology, Department of Internal Medicine, University of Nebraska Medical Center, Omaha, NE, USA, 68198

bepartment of Medicine, Michigan State University, East Lansing, MI, USA, 48824

'Fred and Pamela Buffett Cancer Center, University of Nebraska Medical Center, Omaha, NE, USA, 68198

${ }^{\mathrm{d} D e p a r t m e n t}$ of Pathology and Microbiology, University of Nebraska Medical Center, Omaha, NE, USA, 68198

\begin{abstract}
- ABSTRACT
Congenital factor VII deficiency is a challenging disorder to manage, as it is associated with varied genotypes that do not clinically correlate with a bleeding phenotype. Individuals with severe factor VII deficiency (FVII: $c<1 \%$ ) might be asymptomatic, while patients with moderate deficiency (FVII: c level $>5 \%)$ may experience severe hemorrhages. In modern medicine, due to extensive routine pre-operative laboratory testing, clinically asymptomatic patients without any bleeding history might be incidentally discovered, raising clinical dilemmas. Careful consideration of bleeding versus thrombosis risk has to be made in such cases, especially in the elderly. Clinical history of no prior bleeding complications may be a reassuring factor. Minimal required replacement dosing of recombinant activated factor VII can be given peri-operatively in such situations, with close monitoring.
\end{abstract}

Keywords: Factor VII deficiency, Factor VII replacement, bleeding.

\section{INTRODUCTION}

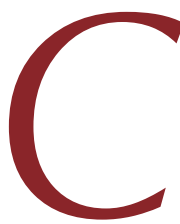

ongenital factor VII deficiency, a rare autosomal hemorrhagic disorder, can have varied clinical presentations, which do not always correlate with the level of factor VII coagulant activity in plasma (1). Asymptomatic patients without any bleeding history might be incidentally discovered, raising clinical dilemmas espe- cially during circumstances such as major surgery (1). Here we describe an elderly woman with incidental diagnosis of congenital factor VII deficiency before an orthopedic surgery.

\section{CASE REPORT}

A 93-year-old woman was admitted after a fall resulting in a left femoral neck fracture. Her past medical history included metabolic syndrome,

Address for correspondence:

Muhamed Baljevic, M.D., Assistant Professor of Medicine Division of Hematology/Oncology, Department of Internal Medicine

University of Nebraska Medical Center I 987680 Nebraska Medical Center I Omaha, NE 68198-7680

Tel: 402-559-8500 office I Fax: 402-559-6520 fax

Email:muhamed.baljevic@unmc.edu

Article received on the $12^{\text {th }}$ of January 2018 and accepted for publication on the $26^{\text {th }}$ of March 2018. 
atrial fibrillation, appendectomy, cholecystectomy and pacemaker implantation without bleeding complications. There was no personal or family history of bleeding disorders. She was evaluated by orthopedics for surgical fixation with arthroplasty. Pre-operative workup showed unremarkable complete blood count with normal chemistry and liver function panels. Interestingly, coagulation studies showed isolated prolongation of prothrombin time (PT) to 32 seconds (s) (reference range: $10.4-13.4 \mathrm{~s}$ ) with International Normalized Ratio (INR) of 2.8. Activated partial thromboplastin time was normal at $28 \mathrm{~s}$. Disseminated intravascular coagulation (DIC) evaluation was unremarkable, with fibrinogen level of $172 \mathrm{mg} / \mathrm{dL}$. The primary care physician who took care of the patient for over two decades reported no bleeding issues. Due to suspected vitamin $\mathrm{K}$ deficiency, she received $10 \mathrm{mg}$ of intravenous vitamin $\mathrm{K}$ for three days, which did not correct the PT; rather it became further prolonged to $48.8 \mathrm{~s}$, with an INR of 3.9. A 1:1 plasma mixing study showed correction of the PT without any inhibitor activity. Lupus anticoagulant was negative. Factor VII coagulant activity (FVII: c) measured (recombinant human tissue factor HemosIL $®$ ReadiPlasTin ${ }^{\circledR}$ on ACLTOP500 $®$ analyzer) was low at $10 \%$. Factor VII antigen level was low at $<28$ (Reference range: $60-175$ ). Other factors were not decreased with activities of Factor $\mathrm{V}$ at $83 \%$, Factor VIII at $286 \%$, and Factor $\mathrm{X}$ at $71 \%$.

The patient had no known liver disorders and was not on anticoagulation therapy. Mixing study showed correction of PT without inhibitor effect to suspect acquired factor VII inhibitors. Vitamin $\mathrm{k}$ deficiency was felt to be unlikely due to normal levels of other vitamin $\mathrm{K}$ dependent factors and failure of response to empiric vitamin K therapy. Disseminated intravascular coagulation (DIC) was also ruled out. Hence, she was diagnosed with an occult congenital factor VII deficiency with an asymptomatic phenotype that might have resulted in undiagnosed biochemical defect through her lifetime. Given potential for significant bleeding with hip arthroplasty, orthopedics requested correction of her coagulopathy. Considering patient's advanced age and atrial fibrillation, large volume thawed plasma infusions were avoided. She instead received perioperative recombinant activated factor VII infusion at a dose of $10 \mathrm{mcg} / \mathrm{kg}$ prior to incision and on post-operative days 1 and 3. Surgery and post-operative course were uneventful, without bleeding or thrombosis in the available 60 days follow up period.

\section{DISCUSSION}

Congenital factor VII deficiency is a challenging disorder to manage, associated with varied genotypes that do not correlate clinically with a bleeding phenotype (1). Individuals with severe factor VII deficiency (FVII: c $<1 \%$ ) might be asymptomatic, while patients with moderate deficiency (FVII: c level >5\%) might experience severe hemorrhages $(2,3)$. However, the risk of bleeding should not be underestimated during hemostatic challenges like major surgery, even in asymptomatic individuals (4). Minimal safe levels of FVII: $c$ that guarantee hemostasis in different clinical scenarios have not been well defined (5). Furthermore, there are no standard guidelines for the management of congenital factor VII deficiency. Nonetheless, knowledge obtained from registries of STER (Seven Treatment Evaluation Registry) and IRF7 (International Registry of Factor VII deficiency) has helped enormously in providing clinical guidance $(6,7)$. The lack of predictable bleeding risk either from the genotype, measured factor activity levels or laboratory clotting assays pose a clinical dilemma in determining the necessity for administration of replacement therapy in an otherwise asymptomatic individual awaiting surgical intervention. The kaolin-based thromboelastography that is often used peri-operatively by surgeons and anesthesiologists would not likely detect this deficiency, as the extrinsic pathway is not interrogated by this method. Perhaps the lack of a clinical bleeding history might be the only reassuring indicator in these cases (8). Nevertheless, significantly prolonged coagulation assays especially prior to surgical procedures create anxiety among care providers. Expert opinion in these situations is to administer a minimal required dosing of replacement therapy to minimize the bleeding risk (6).

Our patient remained undiagnosed, asymptomatic and without any prior bleeding complications throughout her life, despite multiple prior surgeries, but given the significantly prolonged PT and INR prior to a planned major orthopedic procedure, we administered dose-reduced recombinant activated factor VII to correct her 'COagulopathy'. We did not encounter any throm- 
botic complications, but one needs to be mindful of this even in patients with symptomatic factor VII deficiency (9).

\section{CONCLUSION}

$\mathrm{O}$ ur case is rare in the fact that a 93-year-old woman finally received a diagnosis for congenital factor VII deficiency, which went unno- ticed for nearly a century. It also highlights the variable phenotypes that exist with this disorder, and the ensuing clinical dilemma it can generate during their perioperative management.

Conflicts of Interest: none declared.

Financial support: none declared.

\section{References}

1. Napolitano M, Siragusa S, Mariani G. Factor VII deficiency: Clinical phenotype, genotype and therapy. J Clin Med 2017;4:38.

2. Perry DJ. Factor VII deficiency. Br J Haematol 2002;3:689-700.

3. Mariani G, Bernardi F. Factor VII deficiency. Semin Thromb Hemost 2009;4:400-406

4. Benlakhal F, Mura T, Schved J, Giansily-Blaizot M. French study group of factor VIID. A retrospective analysis of 157 surgical procedures performed without replacement therapy in 83 unrelated factor VII-deficient patients.
J Thromb Haemost 2011;9:1149-1156.

5. Giansily-Blaizot $M$, Verdier $R$,

Biron-Adreani C, et al. Analysis of biological phenotypes from 42 patients with inherited factor VII deficiency: Can biological tests predict the bleeding risk? Haematologica 2004;6:704-709.

6. Mariani G, Dolce A, Batorova A, et al. Recombinant, activated factor VII for surgery in factor VII deficiency: A prospective evaluation - the surgical STER. Br J Haematol 2011;3:340-346.

7. Napolitano M, Di Minno, Matteo Nicola Dario, Batorova A, et al. Women with congenital factor VII deficiency: Clinical phenotype and treatment options from two international studies. Haemophilia 2016;5:752-759.

8. Blaizot MG, Biron-Andreani C, AguilarMartinez P, et al. Inherited factor VII deficiency and surgery: Clinical data are the best criteria to predict the risk of bleeding. Br J Haematol 2002;1:172-175.

9. Mariani G, Herrmann F, Schulman S, et al. International factor VII deficiency study group. J Thromb Haemost 2003;1:2153-2158.
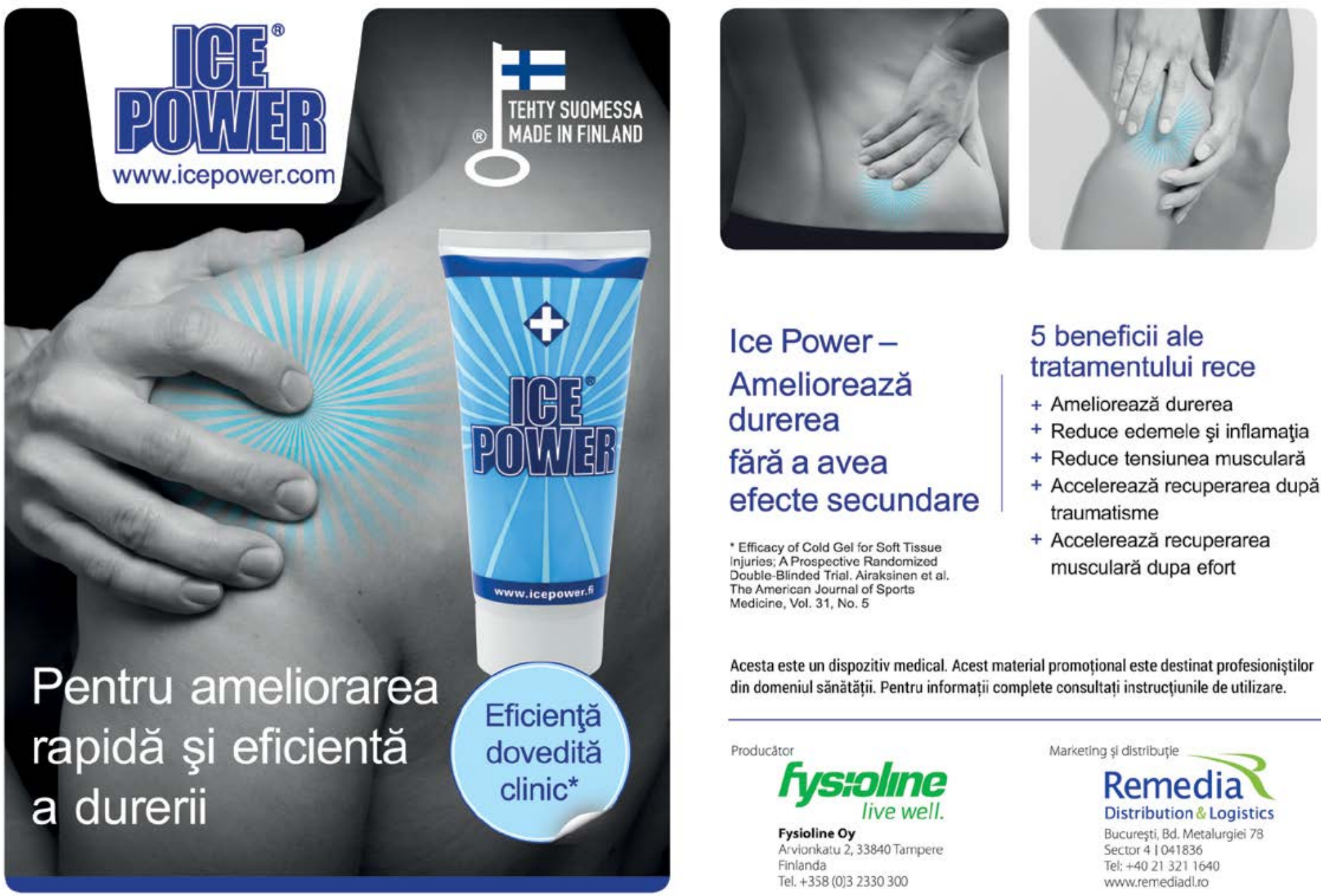

\section{Ice Power -}

Ameliorează durerea

fără a avea efecte secundare

- Efficacy of Cold Gel for Soft Tissue Injuries; A Prospective Randomized Double-Blinded Trial. Airaksinen et Medicine, Vol. 31, No. 5
Acesta este un dispozitiv medical. Acest material promoțional este destinat profesioniştilor din domeniul sănătății. Pentru informații complete consultați instrucțiunile de utilizare.

\section{5 beneficii ale tratamentului rece \\ + Ameliorează durerea \\ + Reduce edemele şi inflamaţia \\ + Reduce tensiunea musculară \\ + Accelerează recuperarea după traumatisme \\ + Accelerează recuperarea musculară dupa efort}

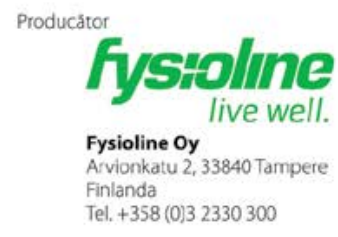

Remedia

Distribution \& Logistics Bucureşti, Bd. Metalurgiei 78 Sector 41041836 Tel: +40213211640 www.remediadl.ro 


\section{O călătorie spre centrul durerii articulare}

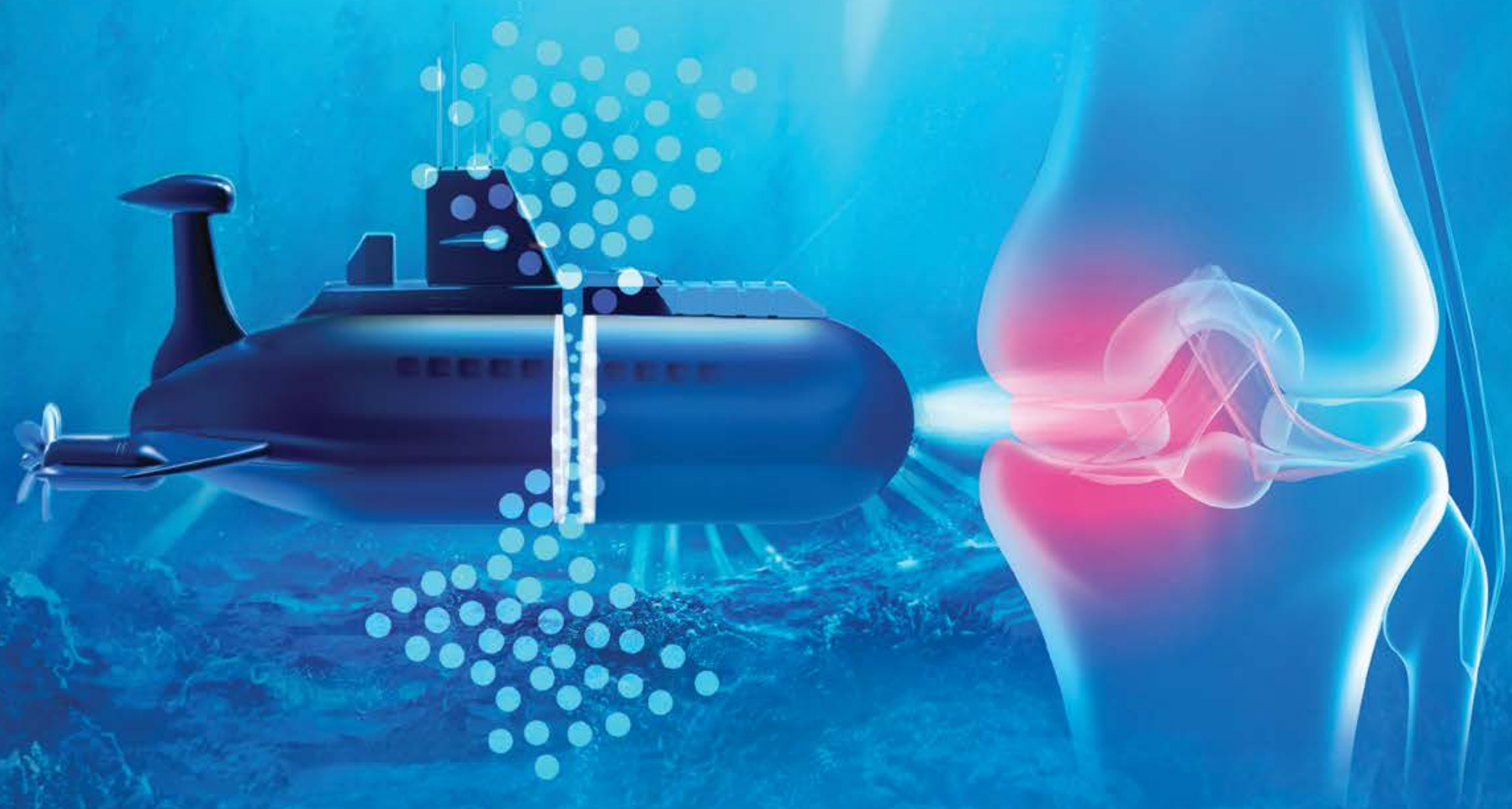

Qent:

Alege un partener loial, pentru un drum fără durere!

\section{DICLGREUM 150m}

capsule cu ellberare prelungitá

Acest material promoțional este destinat profesioniştilor din domeniul sănătății. Dicloreum $150 \mathrm{mg}$ capsule cu eliberare prelungită se eliberează pe bază de prescripție medicală $\mathrm{P} 6 \mathrm{~L}$. Pentru informații suplimentare vă rugăm să consultați rezumatul caracteristicilor produsului complet, disponibil la cerere. Profesioniştii din domeniul sănătăţii sunt rugaţi să raporteze orice reacţie adversă suspectată la Alfasigma România S.R.L la adresa de email: drugsafety.ro@alfasigma.com sau ANMDM. 